\title{
Banks' Performance and Economic Growth in India: A Panel Cointegration Analysis
}

\author{
Md. Shabbir Alam ${ }^{1, *(D)}$, Mustafa Raza Rabbani ${ }^{2} \mathbb{D}$, Mohammad Rumzi Tausif ${ }^{3}$ and Joji Abey ${ }^{4, *}$ \\ 1 Department of Finance and Economics, College of Commerce and Business Administration, Dhofar \\ University, Salalah 211, Oman \\ 2 Department of Economics and Finance, College of Business Administration, University of Bahrain, \\ Zallaq 32038, Bahrain; mrabbani@uob.edu.bh \\ 3 College of Business Administration, Prince Sattam Bin Abdulaziz University, Al-kharj 165, Saudi Arabia; \\ m.tausif@psau.edu.sa \\ 4 Department of Finance and Accounting, College of Business Administration Kingdom University, \\ Rifa 40434, Bahrain \\ * Correspondence: shabbir.alam28@gmail.com or mdshabbir@du.edu.om (M.S.A.); j.abey@ku.edu.bh (J.A.)
}

Citation: Alam, Md. Shabbir, Mustafa Raza Rabbani, Mohammad Rumzi Tausif, and Joji Abey. 2021. Banks' Performance and Economic Growth in India: A Panel

Cointegration Analysis. Economies 9: 38. https://doi.org/10.3390/ economies 9010038

Received: 28 December 2020

Accepted: 4 March 2021

Published: 14 March 2021

Publisher's Note: MDPI stays neutral with regard to jurisdictional claims in published maps and institutional affiliations.

Copyright: (c) 2021 by the authors. Licensee MDPI, Basel, Switzerland. This article is an open access article distributed under the terms and conditions of the Creative Commons Attribution (CC BY) license (https:/ / creativecommons.org/licenses/by/ $4.0 /)$.

\begin{abstract}
The banking sector plays a crucial role in the economic growth of a nation. The purpose of this study is to examine the long-term association between banks' performance and the economic growth of a developing economy: India. The study used a panel of data of 20 public sector banks for the period 2009 to 2019. It applied the Pedroni and Kao test of co-integration, panel vector error correction model (VECM) dynamic, panel fully-modified ordinary least squires OLS (FMOLS), and dynamic OLS (DOLS) to estimate the relationship of interest margin return on assets, bank investment, and lending capacity of the bank with gross domestic product (GDP) of the country. The identification and incorporation of these bank-related variables are the innovations of this study. The results indicate that the bank-related variables are co-integrated with economic growth. Further analysis indicates a significant relationship between interest margin and return on assets with economic growth. In addition, lending capacity and investment activities are not significantly associated with economic growth, leading to the policy recommendation to improve upon these two factors in order to achieve higher growth rates.
\end{abstract}

Keywords: bank performance; economic growth; return on assets; bank investment; panel cointegration; India

JEL Classification: E44; G21; O11; O16

\section{Introduction}

The financial services industry plays a significant part in the overall growth of an economy by generating employment, providing various investment avenues to the investors and financial services to the customers and the community (Berger et al. 1999). Economic growth actually leads to economic development, for which capital required is provided through the financial services industry (Beckett et al. 2000). Capital formation through the mobilization of resources by the financial services industry and accumulation should be the key element of economic growth strategy (Berger 2000). The banks in the economy aid in making funds accessible by moving excess funds from depositors (with no instant requirements of those funds) and channeling those funds as a credit to investors who have excellent ideas for generating surplus funds in the economy, but have a deficiency of the funds to implement those ideas (Nwanyanwu 2010). This generates income for the banks, ensuring profitability. It is enlightening to understand that the banking sector is a prominent one in the financial sector, as it has stood as one of the most extensive means of attracting many developing nations (Adeniyi 2006). 
The relationship between a country's financial sector and the overall performance of a country's economy has been evaluated in various studies (Aurangzeb 2012; Tabash and Dhankar 2014; Abedifar et al. 2016; Boukhatem and Moussa 2018). All of these studies have jointly hypothesized that this relationship's significance is not a static parameter but a dynamic concept. Moreover, economies with a highly established financial system develop their economy at a high rate. However, banks and other financial institutions stay at the forefront of contributing to economic growth through their activities, such as giving resources to the general public and lending funds to various organizations for their progress and economic development. The financial sector, which is comprised of banks and other lending institutions, leads to sustainable economic growth by engaging in profitable investments and equalizing savings from surplus areas to areas of deficit.

Agreement on banks' significance in the economy is a matter of much academic interest. There is a lot of disagreement on the extent of its contribution to the economy, which is also debatable. Past studies have focused on a variety of measures of banks' size to describe variations of the banks on the economic progression. Very few studies have tried to examine the influences of banks' profitability on the development of the economy.

\section{Theories and Literature Review}

The two main theories available in literature that explain the role of banking performance variables and economic development are given below.

\subsection{Theories}

Schumpeter (1911) highlighted the value of finance in the development of the economic process. Additionally, the study focused on the significance of financial services in enhancing economic development and discussed the conditions when the financial sector might actively promote innovation and growth by examining and sponsoring productive investments. The mission of the Reserve Bank is to develop the convenience of proper financial facilities in the areas where banks still do not exist, ensuring access to financial services for all. More financial inclusion more will be the money circulation in the economy, which boosts the economy. Specifically, Robinson (1952) explained that as the demand for financial services rises, the output also rises, which favors the process of financial development. Other things being equal, the financial sector progress follows growth by earning through interest and assets (Srivastava 2012).

\subsubsection{Anticipated Income Theory}

H.V. Prochnow in 1945 developed this theory, and it suggests that banks must engage themselves in a wide variety of lending activities that may be comprised of amortized real estate mortgage lending, long term loans for generating economic activities, installments loan, and consumer loans by considering the likelihood fact of their repayment as they stimulate the cash flow that enhances liquidity, which depends upon the anticipated income of bank borrowers. This entails that high surplus reserves enhance all types of banks' profitability by enhancing lending investment funds' availability (Saeed et al. 2018).

\subsubsection{Endogenous Growth Theory}

Endogenous growth theory focuses on describing that economic development rate is a consequence of endogenous factors rather than external factors. Internal factors of institutions, such as investment decisions and innovation, or levels of technology change affect the economic growth process. Moreover, the theory also holds that long-run economic growth naturally depends upon financial institutions' policy measures (Romer 1994). The endogenous growth model expounds that inner elements disturb economic progress, even affecting exogenous productivity. The theory helps establish a framework of the relationship of variables used in the study, i.e., the link between the financial industry and the economy's progress. 


\subsection{Literature Review}

For sustainable economic growth, the mobilization of domestic resources, self-reliance objectives, and the efficient utilization of investments are key policy focuses (Nasir et al. 2004). The causality exists in both ways between investment and economic growth (Bint-e-Ajaz and Ellahi 2012), but Madsen (2002) identified that investment mainly causes economic growth. Liang and Reichert (2006) conducted a study for developing and advanced countries, and revealed a causal association between financial sector growth and the development of an economy. The analysis proved causality between two variables, but the relationship was found to be more apparent in developing nations. The association between the financial sector and the growth of the economy has remained an essential concern to researchers. The profitability of a bank can influence the gross domestic product (GDP) by effecting financial stability. Greater bank profitability can enhance financial stability, which is beneficial for growth. As they offer higher returns to shareholders, banks can afford to raise capital from markets (Flannery and Rangan 2008). Rancière et al. (2008) suggest that nations with few fiscal emergencies are likely to experience higher growth than nations with constant financial fluctuations. This finding has been supported by the argument that financial liberties can increase emergencies, but they can also foster financial growth. Therefore, banks' profitability does not need to lead to the economy's positive growth through financial stability.

Tahir (2008) conducted research for Pakistan, and found a one-way causality amid the economic and financial industry's progress in the short and long term. Similarly, Awdeh (2012) found a one-way causal association from the economy's growth to the financial industry in Lebanon, supporting the growth-led finance hypothesis. Aurangzeb (2012), using time series analysis and causal analysis, found that the banking industry contributes considerably to Pakistan's economic improvement. Sharma and Ranga (2014) studied the Indian economy and determined that banks' saving deposits have a significantly affirmative effect on GDP. Emecheta and Ibe (2014) found that there is a significantly affirmative relationship between bank economic development and credit to the private sector and broad money in Nigeria. Mushtaq (2016) conducted a causal analysis and co-integration analysis for Pakistan from 1961 to 2013 amid economic progress and banking activity (deposit and credit) in Pakistan.

Hou and Cheng (2017) explored the short-term and long-term effects of banks' performance indicators on economic growth by using the generalized method of moments (GMM) method. The study indicates that the effect of the indicators depends on the growth of banks and the nation's income over time. The study strongly recommends that economies engage themselves in various financial activities to confirm a sustainable economic growth process. Saeed et al. (2018), through panel (Vector error correction model) VECM and using bank investment, innovation, lending capability, and interest margin, found innovations and bank investment to be the significant determinants of economic growth. Liu and Zhang (2018) explored the endogenous growth process amid the economy's financial system and growth. The study was based on panel data of 29 provinces of China. The study's theoretical findings demonstrated that there is a presence of an optimal financial structure that could meet various demands in the economic development process. The profitability of banks increases the financial stability of the economy, which helps in the growth of the nation (Claeys and Schoors 2007; Arena 2008). The more excellent financial stability helps achieve a stable economy. Pisedtasalasai and Edirisuriya (2020) studied diversification and the performance of commercial banks in Sri Lanka. The study found a two-way connection amid diversification and performance. It revealed an improvement in profitability of banks due to diversification.

A few researchers have not found much of a significant relationship between the financial sector and economic development like Robinson (1952) found to indicate finance as a reasonably insignificant economic growth variable. A study by Salami (2018) on the effect of interest rate on economic growth in Swaziland found a negative and significant association between the deposit interest rate (DIR) and GDP. This has been connected to the 
way that DIR is the income of the deposit money banks, which might be utilized as lendable assets that may support profitability. Likewise, DIR is on money earned by the holders of the stores, so such monies can be transferred once again into the economy by a method for reinvestment that may thus enhance monetary development. It is normal that strategy creators on DIR would keep up stable arrangements that would empower stores/deposits, so that out of gear money could be changed over to methods for re-creation or means of production. A negative impact hence can be concluded that banks are paying more interest than they are receiving. The sample banks are public sector, but one of the reasons again could be that the ease of availing loans from private banks erodes the interest income of public sector banks.

The above kinds of literature (as per Table 1) clearly come up with the relationship between banks' performance and economic development. However, very few studies have been done in the Indian context with the variables of lending capacity, bank investment, return on assets, interest margin, and the annual growth rate of GDP on panel data from the time period 2009-2019. This time period is significant because it is post-sub-prime crisis of 2008.

Table 1. Summary of Literature.

\begin{tabular}{|c|c|}
\hline Author & Result \\
\hline Pisedtasalasai and Edirisuriya (2020) & $\begin{array}{l}\text { Diversification in terms of assets by banks } \\
\text { leads to improved performance of banks. }\end{array}$ \\
\hline Saeed et al. (2018) & $\begin{array}{l}\text { Using bank investment, innovation, lending } \\
\text { capability, and interest margin found } \\
\text { innovations and bank investment as the } \\
\text { significant determinants of economic growth. }\end{array}$ \\
\hline Salami (2018) & $\begin{array}{l}\text { The impact of interest rates on economic } \\
\text { growth in Swaziland found a negative and } \\
\text { significant relationship between the deposit } \\
\text { interest rate and gross domestic product } \\
\text { (GDP). }\end{array}$ \\
\hline Tahir (2008); Mushtaq (2016) & $\begin{array}{l}\text { One-way causality amid the economy and } \\
\text { financial industry's progress in the short and } \\
\text { long term in Pakistan. }\end{array}$ \\
\hline $\begin{array}{l}\text { Babatunde et al. (2013); Claeys and Schoors } \\
\text { (2007); Arena (2008); Liu and Zhang (2018) }\end{array}$ & $\begin{array}{l}\text { Profitability, loans, and advances are positively } \\
\text { and significantly affecting economic growth, } \\
\text { while banks' deposits and assets do not } \\
\text { influence Malaysia's economic growth. }\end{array}$ \\
\hline $\begin{array}{l}\text { Awdeh (2012); Nasir et al. (2004); Emecheta } \\
\text { and Ibe (2014); Flannery and Rangan (2008); } \\
\text { Hou and Cheng (2017) }\end{array}$ & $\begin{array}{l}\text { Banking activity and economic performance } \\
\text { are positively related. }\end{array}$ \\
\hline Rancière et al. (2008) & $\begin{array}{l}\text { Few fiscal emergencies are likely to experience } \\
\text { higher growth than nations with constant } \\
\text { financial systems. }\end{array}$ \\
\hline Tahir et al. (2015) & $\begin{array}{l}\text { Found a short-term, causal association between } \\
\text { bank lending and economic development. }\end{array}$ \\
\hline $\begin{array}{l}\text { Liang and Reichert (2006); Bint-e-Ajaz and } \\
\text { Ellahi (2012); Aurangzeb (2012) }\end{array}$ & $\begin{array}{l}\text { Two-way causality between investments and } \\
\text { economic growth. }\end{array}$ \\
\hline Madsen (2002) & $\begin{array}{l}\text { One way causality from investment to } \\
\text { economic growth. }\end{array}$ \\
\hline
\end{tabular}

Source: made by the authors.

\section{Research Methodology}

The structure of these studies was built on panel data of scheduled commercial banks from 2009 to 2019. The scheduled commercial banks were comprised of 28 banks in 2009, 
including the State Bank of India and its associate. However, it came down to only 20 banks in 2019, because of a few banks' mergers. Thus, this study finally considered those 20 banks which existed throughout the study. The period has been selected as the banks faced severe challenges after the financial meltdown of 2007-2008. The data is obtained from the official website of the Reserve Bank of India and Federal reserve economic data (fred.stlouisfed.org), accessed on 22 September 2020. The variables and their measures are summarized in Table 2 below.

Table 2. Variables for study, their measure, hypotheses, and literature.

\begin{tabular}{|c|c|c|c|}
\hline Determinant/Variable & Measure/Proxy & Hypothesis (H) & Literature \\
\hline Lending capability & $\begin{array}{l}\text { Natural logarithm of total } \\
\text { credit }\end{array}$ & $\begin{array}{l}\mathrm{H}_{1} \text { : The bank lending channel } \\
\text { effect is negative in the long } \\
\text { run to the economic growth of } \\
\text { low income countries. }\end{array}$ & Tahir et al. 2015 \\
\hline Bank investment & $\begin{array}{l}\text { Natural logarithm of } \\
\text { investments }\end{array}$ & $\begin{array}{l}\mathrm{H}_{2} \text { : The investment activities } \\
\text { of banks have a positive } \\
\text { impact in the long run to the } \\
\text { economic growth process of } \\
\text { the country. }\end{array}$ & $\begin{array}{c}\text { Bint-e-Ajaz and Ellahi 2012; } \\
\text { Nasir et al. } 2004\end{array}$ \\
\hline Interest margin & $\begin{array}{l}\text { Natural Logarithm of Net } \\
\text { interest margin }\end{array}$ & $\begin{array}{c}\mathrm{H}_{3} \text { : The interest margin of } \\
\text { banks negatively affect the } \\
\text { process of economic } \\
\text { development }\end{array}$ & $\begin{array}{l}\text { Neumeyer and Perri 2005; } \\
\text { Anari and Kolari } 2016\end{array}$ \\
\hline Return on assets (ROA) & Natural Logarithm of ROA & $\begin{array}{c}\mathrm{H}_{4} \text { : The return on assets of } \\
\text { banks positively affects the } \\
\text { process of economic } \\
\text { development }\end{array}$ & $\begin{array}{c}\text { Babatunde et al. (2013); } \\
\text { Claeys and Schoors (2007); } \\
\text { Arena (2008) }\end{array}$ \\
\hline
\end{tabular}

Source: Authors' own calculation.

A panel data co-integration has been conducted to check long-term association amid identified variables and economic development, but prior to that, the data has been subject to the property checks of a time series. A panel unit root test has been conducted to check the stationary property. The model taken for the study is

$$
\operatorname{LnY} i, t=\beta o+\beta 1 \operatorname{LnLei,t}+\beta 2 \operatorname{Lninvi,t}+\beta 3 \operatorname{Ln} R O A i, t+\beta 4 \operatorname{Ln} i n t i, t+\mu i, t
$$

where; Le- denotes lending capacity, inv- denotes bank investment, $R O A$ - denotes return on assets, int- denotes interest margin, and the annual growth rate of GDP is taken as a measure of the growth of the economy $(Y)$.

\subsection{Panel Unit Root Tests}

The panel unit root test is considerably superior to that of the standard time-series unit root test in finite samples. The study employs various tests of the panel unit root, which is comprised of the LLC test, introduced by Levin et al. (2002); the IPS test, proposed by Im et al. (2003); and Fisher-type tests using ADF and PP tests, proposed by Maddala and $\mathrm{Wu}$ (1999). In Table 3, the LLC test's null hypothesis presumes that there is a standard unit root across the cross-sections, whereas the alternative hypothesis assumes no unit root across the cross-sections. The IPS, Fisher-PP, and Fisher-ADF tests presume that the individual unit root process prevails across all the cross-sections in Table 3. The null hypothesis of all three tests states that there is a unit root across the cross-sections of variables, whereas the alternative hypothesis state that there is no unit root across the cross-sections. 
Table 3. Summary of group unit root test at level form.

\begin{tabular}{ccccc}
\hline & Series: Lending Capacity, GDP, Investment, Net Interest Margin, Return on Assets \\
\hline Test & LLC & IPS & ADF Fisher \\
\hline Null & Considers the common unit root process & \multicolumn{2}{c}{ Considers individual unit root process } \\
Value & -0.27157 & -11.8294 & 185.680 & 233.890 \\
Significance & 0.3930 & 0.0000 & 0.0000 & 0.0000 \\
\hline
\end{tabular}

Note: Authors' own calculation.

The group panel test result through LLC suggests a unit root in the group sample, whereas IPS, ADF, and PP all suggest a positive relationship, which means the series is free from the unit root at the individual level. The panel group test further has been done for the first difference to get a stationary group shown in Table 4.

Table 4. Summary of group unit root test at first difference form.

\begin{tabular}{ccccc}
\hline & \multicolumn{2}{c}{ Series: Lending Capacity, GDP, Investment, Net Interest Margin, Return on Assets } \\
\hline Test & LLC & IPS & ADF Fisher & PP Fisher \\
\hline Null & Considers the common unit root process & \multicolumn{2}{c}{ Considers individual unit root process } \\
Value & -3.09936 & -19.8385 & 296.642 & 279.060 \\
Significance & $0.0010^{*}$ & $0.0000^{*}$ & $0.0000^{*}$ & $0.0000^{*}$ \\
\hline
\end{tabular}

Source: Authors' own calculation. * Denotes significance at $1 \%$ level of significance

Hence, at the first difference, all variables are stationary and integrated to order one I(1).

\subsection{Panel Co-Integration Test}

The Engle and Granger (1987) examines a false regression's residuals done through I(1) variables or factors. It suggests that if factors are integrated, the residuals will be integrated at the level, and if not, then first order integration will be found.

$$
Y_{i t}=\alpha_{i}+\sum_{q=1}^{w} \beta_{q i} X_{q i t}+\varepsilon_{i t}
$$

where $i=1, \ldots, N$ indicates each bank in the sample and $t=1, \ldots, T$ indicates the period. The variable $\alpha_{i}$ permits bank-specific fixed effects. The term $\varepsilon_{i t}$ signifies expected residuals, which demonstrate the deviation from a long-term association in the process. The fixed effect is used because the chi square statistic of Hausman test rejected the null hypothesis of random. The hypothesis of no co-integration $\left(R_{i}=1\right)$ is assessed by residuals as follows:

$$
\varepsilon_{i t}=R_{i} \varepsilon_{i}(t-1)+M_{i t}
$$

In this study, two tests of co-integration have been used. The first test is Pedroni (2004), and the second test is Kao (1999), which is based on Engle-Granger and enforces homogeneity on units in the panel set.

\subsection{Pedroni Test for Panel Cointegration}

For this test, the following regression equation is used:

$$
y i t=\alpha i+\delta i t+\beta 1 i x 1 i, t+\beta 2 i x 2 i, t+\ldots+\beta m i x m i, t+e i, t
$$

where $t=1, \ldots \ldots \ldots, T ; i=1, \ldots \ldots \ldots, N ; m=1, \ldots \ldots, M$ and $x$ is expected to be $\mathrm{I}(1)$. The factors $\alpha i$ and $\delta i$ are individual and drift effects, which may be fixed at zero if needed. 
As mentioned above, if there is no co-integration, the residuals ei, $t$ will be I(1). Generally, an auxiliary regression (Equation (5)) is run on the residuals obtained from Equation (4) and tested if I(1) for each cross-section.

$$
e_{i, t}=\rho_{i} t_{i-1}+u_{i t}
$$

3.4. Kao Test for Panel Co-Integration

Kao (1999) suggested that

$$
y_{i t}=\alpha_{i}+\beta X_{i t}+e_{i t}
$$

for

$$
\begin{aligned}
& y_{i t}=y_{i t-1}+u_{i, t} \\
& x_{i t}=x_{i t-1}+\varepsilon_{i, t}
\end{aligned}
$$

where $t=1, \ldots \ldots \ldots, T$ and $i=1, \ldots \ldots \ldots, N$.

Kao then ran the pooled auxiliary regression:

$$
e_{i t}=\rho e_{i t-1}+u_{i t}
$$

The result of panel data in Table 5, co-integration suggests a co-integrating relationship as per the Kao test, because the ADF statistic is significant at a $1 \%$ level of significance. However, the Pedroni test shows no co-integration, as the $p$-values of the panel PP statistics, panel ADF statistics, group PP statistics, and group ADF statistics are insignificant at a $1 \%$ level of significance. Hence, we do not reject the null hypothesis.

Table 5. Test of p co-integration.

\begin{tabular}{cccccc}
\hline Test Name & Test Statistics & Statistic & Probability & Weighted & Probability \\
\hline \multirow{5}{*}{ Pedroni statistics } & Panel v-Statistics & -1.470686 & 0.9293 & -2.218442 & 0.9867 \\
& Panel rho-Statistics & 3.909891 & 1.0000 & 3.812640 & 0.9999 \\
& Panel PP-Statistics & 0.051291 & 0.5205 & -0.369908 & 0.3557 \\
& Panel ADF-Statistics & -0.022509 & 0.4910 & -0.425635 & 0.3352 \\
& Group rho-Statistics & 5.853543 & 1.0000 & - & - \\
& Group PP-Statistics & -0.647024 & 0.2588 & - & - \\
& Group ADF-Statistics & -0.703523 & 0.2409 & - & Prob. \\
Kao Statistics & & & & $t-$ Statistic & $0.0000 *$ \\
\hline
\end{tabular}

Source: Authors' own calculation. ${ }^{*}$ Denotes significance at $1 \%$ level of significance

\subsection{VECM Panel}

After the confirmation of cointegration, a panel vector error correction was conducted to see the convergence or the long run causality. The estimated equation is

$$
\begin{gathered}
\mathrm{D}(\mathrm{GDP})=\mathrm{C}(1)^{*}\left(\mathrm{GDP}(-1)+0.000640025904353^{*} \operatorname{INTMARGIN}(-1)\right. \\
-0.00167270624665^{*} \operatorname{INVESTMENT}(-1)+5.44422569915 \mathrm{E}-05^{*} \mathrm{LE}(-1) \\
\left.-0.00253819452049^{*} \mathrm{RA}(-1)-0.0741922972213\right)+\mathrm{C}(2) * \mathrm{D}(\mathrm{GDP}(-1)) \\
+\mathrm{C}(3)^{*} \mathrm{D}(\mathrm{GDP}(-2))+\mathrm{C}(4)^{*} \mathrm{D}(\mathrm{INTMARGIN}(-1))+\mathrm{C}(5) * \mathrm{D}(\operatorname{INTMARGIN}(-2)) \\
+\mathrm{C}(6) * \mathrm{D}(\operatorname{INVESTMENT}(-1))+\mathrm{C}(7) * \mathrm{D}(\operatorname{INVESTMENT}(-2)) \\
+\mathrm{C}(8) * \mathrm{D}\left(\mathrm{LE}(-1)+\mathrm{C}(9)^{*} \mathrm{D}(\mathrm{LE}(-2))+\mathrm{C}(10)^{*} \mathrm{D}(\mathrm{RA}(-1))+\mathrm{C}(11) * \mathrm{D}(\operatorname{RA}(-2))+\mathrm{C}(12)\right.
\end{gathered}
$$

Here, in Table 6 depicted C(1) is the error correction term (ECT), which has been found to be negative and significant $(-1.8915)$. This indicates the convergence, i.e., the values get back to its mean value in the long run. Normally, the value of ECT should be between 0 and -1 , but values between -1 and -2 are also probable and also indicate convergence, but with dampened fluctuations (Narayan and Smyth 2006). 
Table 6. Value of coefficients.

\begin{tabular}{ccccc}
\hline & Coefficient & Std. Error & $\boldsymbol{t}$-Statistic & Probability \\
\hline$C(1)$ & -1.891590 & 0.098550 & -19.19421 & 0.0000 \\
$C(2)$ & 0.814919 & 0.069943 & 11.65118 & 0.0000 \\
$C(3)$ & 1.410280 & 0.123827 & 11.38913 & 0.0000 \\
$C(4)$ & 0.005120 & 0.002779 & 1.842436 & 0.0658 \\
$C(5)$ & 0.002089 & 0.002786 & 0.749931 & 0.4535 \\
$C(6)$ & -0.002445 & 0.003567 & -0.685551 & 0.4932 \\
$C(7)$ & -0.002943 & 0.004057 & -0.725527 & 0.4684 \\
$C(8)$ & -0.000110 & 0.000172 & -0.639393 & 0.5228 \\
$C(9)$ & 0.000106 & 0.000171 & 0.622498 & 0.5338 \\
$C(10)$ & -0.005120 & 0.001426 & -3.591523 & 0.0004 \\
$C(11)$ & -0.000850 & 0.000959 & -0.886805 & 0.3755 \\
$C(12)$ & -0.000604 & 0.000790 & -0.764092 & 0.4451 \\
\hline
\end{tabular}

Source: Authors' own calculation.

In other words, long-run causality runs from independent variables, especially interest margin and return on GDP assets.

\subsection{Fully Modified OLS (FMOLS) and Dynamic OLS (DOLS) Panel}

Though the OLS regression suggests a convergence in panel data, sometimes OLS leads to biased estimates. Thus, to confirm the estimates, this study conducted fully-modified OLS (FMOLS) and dynamic OLS (DOLS) below in table. FMOLS is a non-parametric approach. Furthermore, in order to deal with the corrections of serial correlation, FMOLS considers a possible correlation between the first difference of the regressors, the error term, and the presence of the constant term (Maeso-Fernandez et al. 2006). Both tests produce consistent estimates of the standard error, which can be used for postulation. The DOLS is a complete parametric approach and proposes a computationally fitting substitute to the FMOLS panel (Phillips and Moon 1999; Pedroni 2004); however, the downside of the DOLS estimator is that the degree of freedom gets lowered by leads and lags (Maeso-Fernandez et al. 2006). There are a number of options available for estimating the co-integration vector by using the panel data set, including with- and between-group-for instance, FMOLS and DOLS estimation techniques (Pedroni 2001) in Table 7.

Table 7. Fully-modified OLS (FMOLS) and dynamic OLS (DOLS) results.

\begin{tabular}{ccccc}
\hline \multirow{2}{*}{$\begin{array}{c}\text { Dep. Variable of } \\
\text { Eco. Growth }\end{array}$} & \multicolumn{2}{c}{ FMOLS Results } & \multicolumn{2}{c}{ DOLS } \\
\cline { 2 - 5 } & Coefficient & Probability & Coefficient & Probability \\
\hline Lending capability & 2.168183 & 0.1865 & 0.000237 & 0.8527 \\
Return on asset & 0.003645 & $0.0000^{*}$ & 0.007509 & 0.1053 \\
Interest margin & -0.009190 & $0.0000^{*}$ & -0.035686 & 0.0082 \\
Bank investment & -0.000455 & 0.9220 & 0.041161 & 0.1533 \\
\hline
\end{tabular}

Source: Authors' own calculation. ${ }^{*}$ Significant at $1 \%$ level of significance.

If the co-integration exists among the study variables, then we use FMOLS estimations to identify the long-run association between economic growth, return on assets, lending capability, interest margin, and bank investment. In a co-integrated panel data set, if the OLS method for estimating the long-run equation is used, it results in biased estimation of the variables. Thus, the OLS estimation technique is unable to produce valid inference.

A residual diagnosis has also been conducted below Table 8, which found the data to be normally distributed (shown in Figure A1 in Appendix A), as the value of JB test statistics was 4.924 ( $p$-value $=0.08525)$, which is insignificant at a $5 \%$ level of significance. 
Table 8. Residual analysis.

\begin{tabular}{ccc}
\hline \multirow{2}{*}{ Test of Normality } & Jarque-Bera & $p$-Value \\
\cline { 2 - 3 } & 4.9242 & 0.085252 \\
\hline \multirow{2}{*}{ Test of Heteroskedasticity } & Breusch-Pagan-Godfrey statistics & $\boldsymbol{p}$-Value \\
\cline { 2 - 3 } & 168.856 & 0.0790 \\
\hline Source: Authors' $^{\prime}$ own caluation &
\end{tabular}

Source: Authors' own calculation.

The Breusch-Pagan-Godfrey test is a Lagrange multiplier test of the null hypothesis of no heteroskedasticity against heteroskedasticity. The value is insignificant at a $5 \%$ level of significance.

As per the result mentioned in Table 9, the PAC and AC values for autocorrelation analysis turned out to be insignificant at $1 \%$ and $5 \%$ of the significance of the first difference level. The Durbin-Watson value was also 2.95.

Table 9. Test of auto-correlation.

\begin{tabular}{|c|c|c|c|c|c|c|c|c|}
\hline \multicolumn{2}{|c|}{ Autocorrelation } & \multicolumn{3}{|c|}{ Partial Correlation } & \multirow{2}{*}{$\begin{array}{c}\text { AC } \\
0.010\end{array}$} & \multirow{2}{*}{$\begin{array}{l}\text { PAC } \\
0.010\end{array}$} & \multirow{2}{*}{$\begin{array}{c}q \text {-Statistics } \\
0.0213\end{array}$} & \multirow{2}{*}{$\begin{array}{c}\text { Probability } \\
0.884\end{array}$} \\
\hline .1. & I & .1. & I & 1 & & & & \\
\hline$* 1$. & I & $* 1$. & I & 2 & -0.069 & -0.069 & 1.0029 & 0.606 \\
\hline$* * 1$. & I & $* * 1$. & I & 3 & -0.240 & -0.240 & 12.837 & 0.005 \\
\hline$* * 1$. & । & $* * 1$. & । & 4 & -0.235 & -0.255 & 24.261 & 0.000 \\
\hline$* 1$ & I & $* * 1$. & I & 5 & -0.193 & -0.277 & 31.995 & 0.000 \\
\hline $.1^{*}$ & । & .1 & । & 6 & 0.122 & -0.024 & 35.117 & 0.000 \\
\hline .1. & I & $* 1$. & I & 7 & 0.038 & -0.153 & 35.423 & 0.000 \\
\hline $.1^{*}$ & I & $* 1$. & । & 8 & 0.114 & -0.084 & 38.158 & 0.000 \\
\hline .1. & I & $* 1$. & । & 9 & -0.047 & -0.191 & 38.619 & 0.000 \\
\hline
\end{tabular}

Source: Authors' own calculation. * significance at $1 \%,{ }^{* *}$ significance at $5 \%$ level of significance.

\section{Findings}

In this study, we examined the co-integration relationship between lending capability, bank investment, return on assets, interest margin, and India's economic growth for the period 2009 to 2019. For this purpose, the study used different panel unit root tests and panel co-integration tests to analyze the long-run and short-run dynamics between banking development variables and economic growth. The empirical findings are mixed in nature, as the LLS test for panel unit root suggested it was stationary at first difference level form, whereas others were at level form. However, LLS is for the group, so it is an important measure that needed to be further tested at first difference. This made the variable I(1).

Similarly, panel co-integration results were mixed, because the Pedroni test of cointegration suggested no co-integration, whereas the Kao test suggested co-integration. After the confirmation of co-integration, the vector error correction analysis was performed to check the error correction term's coefficient. The ECT was found to be negative and significant through ordinary least square, which suggested convergence.

Furthermore, to avoid OLS's biases, and for estimating the coefficients, the fully modified ordinary least square has been used, which suggests a long-term association of return on assets and interest margin with economic growth, whereas there was no association with lending capacity and investments for this sample period. The analysis rejects hypothesis $1\left(\mathrm{H}_{1}\right)$, that the investment activities of banks positively impact the short and long run of the country's economic growth process. However, there was a negative association between interest margin and economic development, as the coefficient of interest margin was -0.0091 , which is negative and significant. The results of the analysis again support the third hypothesis $\left(\mathrm{H}_{3}\right)$, that the return on assets positively affects economic growth in the long run. The coefficient attained was 0.003645, which is positive and significant. The fourth hypothesis $\left(\mathrm{H}_{4}\right)$ was that banks' lending capacity 
negatively affects low-income countries' economic growth in the long run, gets rejected, as the coefficient of lending capacity was 2.168183 , which is positive and insignificant.

\section{Conclusions}

The present study's analysis suggests a long-term association between banks' performance and the growth of the economy. Bank profitability enhances growth. Bank profitability measured through return on assets helps economic growth in the long run, as the analysis gave a positive and significant coefficient. The lending capacity, though, is positive but insignificant. These findings support the growth parameters of anticipated income theory and confirmed that different forms of lending activities of the banking sector accelerate the pace of economic growth in less-developed economies. The interest margin has a negative but significant impact on the economy. Though net interest income plays a dominant role in the earning of banks (Angori et al. 2019) from a macro (welfare and monetary policy) perspective, low net interest margins (NIMs) are not necessarily bad. They can be a sign of a relatively competitive banking sector and of lower funding costs for the non-financial private sector. Banks' individual interest rate-setting abilities in highly competitive markets should be limited, potentially resulting in a more complete interest rate pass-through (Van Leuvensteijn et al. (2013); Committee on the Global Financial System (CGFS (2018)).

Investments do not have a significant association with India's growth in the given period. However, endogenous growth theory believes that an increasing rate of bank investment always opens new channels of business activities, which in turn enhances economic development through fund allocation to industrialists. The study confirms that profitability increases financial stability, which is in line with the findings of Claeys and Schoors (2007) and Arena (2008). In general, the analysis backs the observation of Athanasoglou et al. (2008), which suggests that banks' profitability is a precondition for the growth of the economy. Policy creators should be conscious about the effect their policies will have on banks' performance, as those banks have a continuous effect on the economy.

A stable banking sector is crucial for the economic growth of a country. Nevertheless, for the period under study, investment activities of the banks did not significantly impact economic growth. This leads to the scope of future research: to study the investment activities of banks in detail. Similarly, the lending capacity also did not impact economic growth significantly. These hint at unused funds available with the banks, as the lending capacity of banks are not contributing significantly to the economic growth of the country. Furthermore, the study provides evidence for a negative relationship between interest margin and economic growth. In this respect, further research is recommended by incorporating the effectiveness of monetary policy in line with the asymmetric relationship between interest rates and financial markets, as stated by Fullana et al. (2020) Lastly, improving upon the return on assets (ROA) is highly recommended to further economic growth.

The present study, though, found only two variables to be significant, but helps to understand the pattern and behavior of such variables. It helps to understand that how these variables moved in this duration, and how they have influenced the economy of India.

Finally, it is worth mentioning that the use of annual data might prove to be the limitation of our study, as analyzing the data with high frequency might not give the correct impact variables with annual data (Angori et al. 2019). The other limitation of this study is the number of years. If the years are increased, a panel data analysis will give a clearer picture, as a few analyses suggest that individual series might be stationary at the individual level. This can be improved by adding more years and a few more variables of the financial sector leading to economic growth that can be identified.

Author Contributions: Conceptualization-M.S.A., Formal analysis, Methodology M.S.A., M.R.R. and M.R.T., Writing—original draft, Investigation, review \& editing, Project administration, M.S.A. \& M.R.R., Supervision, Validation-M.S.A., J.A., M.R.R., Funding acquisition, Resources, InvestigationJ.A. All authors have read and agreed to the published version of the manuscript. 
Funding: No funding was received from any source.

Data Availability Statement: Data used in this paper are available from the official website of the Reserve Bank of India and Federal reserve economic data (fred.stlouisfed.org) at 22 September 2020. The data will be made available when demanded.

Conflicts of Interest: The authors declare no conflict of interest.

\section{Appendix A}

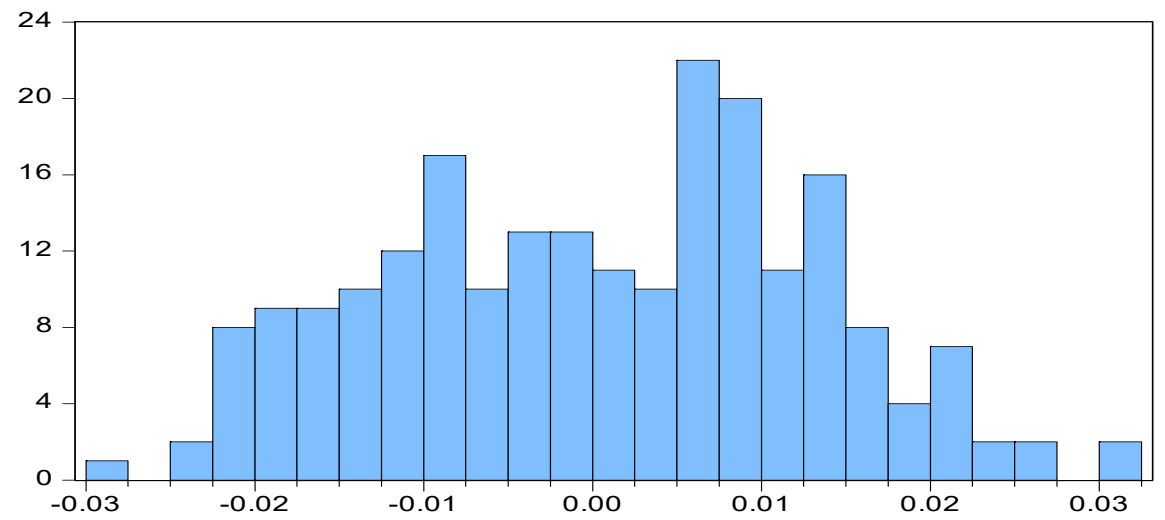

\begin{tabular}{|lr|}
\hline \multicolumn{2}{|l|}{ Series: RESIDO1 } \\
Sample 2009 2019 \\
Observations 219 \\
Mean & 0.000529 \\
Median & 0.001357 \\
Maximum & 0.032205 \\
Minimum & -0.029816 \\
Std. Dev. & 0.012666 \\
Skewness & -0.005198 \\
Kurtosis & 2.265465 \\
& \\
Jarque-Bera & 4.924298 \\
Probability & 0.085252 \\
\hline
\end{tabular}

Figure A1. Test of normality. Source: authors' own calculation.

\section{References}

Abedifar, Pejman, Iftekhar Hasan, and Amine Tarazi. 2016. Finance-growth nexus and dual-banking systems: Relative importance of Islamic banks. Journal of Economic Behavior E Organization 132: 198-215.

Adeniyi, O. M. 2006. Bank Credit and Economic Development in Nigeria: A Case Study of Deposit Money Banks. Jos: University of Jos.

Angori, Gabriele, David Aristei, and Manuela Gallo. 2019. Determinants of banks' net interest margin: Evidence from the Euro area during the crisis and post-crisis period. Sustainability 11: 3785. [CrossRef]

Anari, Ali, and James Kolari. 2016. Dynamics of interest and inflation rates. Journal of Empirical Finance 39: 129-44. [CrossRef]

Arena, Marco. 2008. Bank failures and bank fundamentals: A comparative analysis of Latin America and East Asia during the nineties using bank-level data. Journal of Banking E Finance 32: 299-310.

Athanasoglou, Panayiotis P., Sophocles N. Brissimis, and Matthaios D. Delis. 2008. Bank-specific, industry-specific and macroeconomic determinants of bank profitability. Journal of International Financial Markets, Institutions and Money 18: 121-36. [CrossRef]

Aurangzeb. 2012. Contribution of banking sector in economic growth: A case of Pakistan. Economics and Finance Review 2: 45-54.

Awdeh, Ali. 2012. Banking sector development and economic growth in Lebanon. International Research Journal of Finance and Economics 100: 53-62.

Babatunde, Onakoya, Olaitan Adegbemi, and Adekola Onakoya. 2013. The performance of conventional and Islamic banks in the United Kingdom: A comparative Analysis. Journal of Research in Economics and International Finance (JRELF) 2: 29-38.

Beckett, Antony, Paul Hewer, and Barry Howcroft. 2000. An exposition of consumer behaviour in the financial services industry. International Journal of Bank Marketing 18: 15-26. [CrossRef]

Berger, Allen N. 2000. The integration of the financial services industry: Where are the efficiencies? North American Actuarial Journal 4: 25-45. [CrossRef]

Berger, Allen N., Rebecca S. Demsetz, and Philip E. Strahan. 1999. The consolidation of the financial services industry: Causes, consequences, and implications for the future. Journal of Banking $\mathcal{E}$ Finance 23: 135-94.

Bint-e-Ajaz, Maryam, and Nazima Ellahi. 2012. Public-Private Investment and Economic Growth in Pakistan: An Empirical Analysis. The Pakistan Development Review 51: 61-78.

Boukhatem, Jamel, and Fatma Ben Moussa. 2018. The effect of Islamic banks on GDP growth: Some evidence from selected MENA countries. Borsa Istanbul Review 18. [CrossRef]

CGFS. 2018. Structural changes in banking after the crisis, CGFS Papers No 60, Committee on the Global Financial System. January. Available online: https:/ / www.bisorg/publ/cgfs60.pdf (accessed on 10 March 2021).

Claeys, Sophie, and Koen Schoors. 2007. Bank supervision Russian style: Evidence of conflicts between micro-and macro-prudential concerns. Journal of Comparative Economics 35: 630-57. [CrossRef]

Emecheta, B. C., and R. C. Ibe. 2014. Impact of bank credit on economic growth in Nigeria: Application of reduced vector autoregressive (VAR) technique. European Journal of Accounting Auditing and Finance Research 2: 11-21.

Engle, Robert F., and Clive W. J. Granger. 1987. Co-integration and error correction: Representation, estimation, and testing. Econometrica: Journal of the Econometric Society 55: 251-76. [CrossRef] 
Flannery, Mark, and Kasturi P. Rangan. 2008. What Caused the Bank Capital Build-up of the 1990s? Review of Finance 12: 391-429. [CrossRef]

Fullana, Olga, Javier Ruiz, and David Toscano. 2020. Stock market bubbles and monetary policy effectiveness. The European Journal of Finance, 1-13. [CrossRef]

Hou, Han, and Su-Yin Cheng. 2017. The dynamic effects of banking, life insurance, and stock markets on economic growth. Japan and the World Economy 41: 87-98. [CrossRef]

Im, Kyung So, Hashem M. Pesaran, and Yongcheol Shin. 2003. Testing for unit roots in heterogeneous panels. Journal of Econometrics 115: 53-74. [CrossRef]

Kao, Chihwa. 1999. Spurious regression and residual-based tests for co-integration in panel data. Journal of Econometrics 90: 1-44. [CrossRef]

Levin, Andrew, Chien-Fu Lin, and Chia-Shang James Chu. 2002. Unit root tests in panel data: Asymptotic and finite-sample properties. Journal of Econometrics 108: 1-24. [CrossRef]

Liang, Hshin Yu, and Alan Reichert. 2006. The Relationship between economic growth and Banking sector development. Banks and Bank Systems 1: 19-35.

Liu, Guanchun, and Chengsi Zhang. 2018. Does financial structure matter for economic growth and income inequality in China. China Economic Review, 101194. [CrossRef]

Maddala, Gangadharrao S., and Shaowen Wu. 1999. A comparative study of unit root tests with panel data and a new simple test. Oxford Bulletin of Economics and Statistics 61: 631-52. [CrossRef]

Madsen, Jakob. 2002. The causality between investment and economic growth. Economics Letters 74: 157-63. [CrossRef]

Maeso-Fernandez, Francisco, Chiara Osbat, and Bernd Schnatz. 2006. Towards the estimation of equilibrium exchange rates for transition economies: Methodological issues and a panel cointegration perspective. Journal of Comparative Economics 34: 499-517. [CrossRef]

Mushtaq, Saba. 2016. Causality between bank's major activities and economic growth: Evidences from Pakistan. Financial Innovations 2: 1-11. [CrossRef]

Narayan, Paresh Kumar, and Russell Smyth. 2006. What determines migration flows from low-income to high-income countries? An empirical investigation of Fiji-Us migration 1972-2001. Contemporary Economic Policy 24: 332-42. [CrossRef]

Nasir, Shahbaz, Mahmood Khalid, and Amir Mahmood. 2004. Saving-investment Behaviour in Pakistan: An Empirical Investigation. The Pakistan Development Review 43: 665-82. [CrossRef]

Neumeyer, Pablo A., and Fabrizio Perri. 2005. Business cycles in emerging economies: The role of interest rates. Journal of Monetary Economics 52: 345-80. [CrossRef]

Nwanyanwu, Onyinyechi Josephine. 2010. An Analysis of Bank Credit on the Nigeria Economic Growth (1992-2008). JOS Journal of Economics 4: 43-58.

Pedroni, Peter. 2001. Fully modified OLS for heterogeneous cointegrated panels. In Nonstationary Panels, Panel Cointegration, and Dynamic Panels (Advances in Econometrics, V-15). Edited by Badi H. Baltagi, Thomos Fomby and R. Carter Hill. Bingley: Emerald Group Publishing Limited, pp. 93-130. [CrossRef]

Pedroni, Peter. 2004. Panel co-integration: Asymptotic and finite sample properties of pooled time series tests with an application to the PPP hypothesis. Econometric Theory 20: 597-625. [CrossRef]

Phillips, Peter C. B., and Hyungsik R. Moon. 1999. Nonstationary Panel Data Analysis: An Overview of Some Recent Developments. Cowles Foundation Discussion Papers 1221. New Haven: Cowles Foundation for Research in Economics, Yale University.

Pisedtasalasai, Anirut, and Piyadasa Edirisuriya. 2020. Diversification and performance of Sri Lankan banks. The Journal of Asian Finance, Economics, and Business 7: 1-10. [CrossRef]

Rancière, Romain, Aaron Tornell, and Frank Westermann. 2008. Systemic Crises and Growth. The Quarterly Journal of Economics 123: 359-406. [CrossRef]

Robinson, Joan. 1952. The Generalisation of the General Theory, in the Rate of Interest, and Other Essays, 2nd ed. London: Macmillan.

Romer, Paul M. 1994. The origins of endogenous growth. Journal of Economic Perspectives 8: 3-22. [CrossRef]

Saeed, Muhammad, Muhammad Ramzan Yasir, and Kashif Hamid. 2018. Dynamics of Banking Performance Indicators and Economic Growth: Long-Run Financial Development Nexus in Pakistan. European Online Journal of Natural and Social Sciences 7: 141-63.

Salami, F. K. 2018. Effect of Interest Rate on Economic Growth: Swaziland As a Case Study. Journal of Business and Financial Affairs 7: $1-5$.

Schumpeter, Joseph A. 1911. The Theory of Economic Development-An Inquiry into Profits, Capital, Credit, Interest, and the Business Cycle. London: Harvard University Press.

Sharma, Deepti, and Mamta Ranga. 2014. Impact of saving deposits of commercial banks on GDP. Indian Journal of Applied Research 4: 95-97.

Srivastava, Ankita. 2012. Determinants of capital structure in Indian public ltd. companies: An experience of pre and post liberalization. Indian Journal of Finance 6: 30-38.

Tabash, Mosab I., and Raj S. Dhankar. 2014. The flow of Islamic finance and economic growth: An empirical evidence of Middle East. Journal of Finance and Accounting 2: 11-19. [CrossRef]

Tahir, Muhammad. 2008. An investigation of the effectiveness of financial development in Pakistan. Lahore Journal of Econ 13: 27-44. [CrossRef] 
Tahir, Safdar Husain, Iqra Shehzadi, Ishfaq Ali, and Muhammad Rizwan Ullah. 2015. Impact of Bank Lending on Economics Growth in Pakistan: An Empirical Study of Lending to Private Sector. American Journal of Industrial and Business Management 5: 565-76. [CrossRef]

Van Leuvensteijn, Michiel, Chiristoffer Sørensen, Jacob Bikker, and Adrian Rixtel. 2013. Impact of bank competition on the interest rate pass-through in the euro area. Applied Economics 45: 1359-80. [CrossRef] 